\title{
THE EFFECT OF PLATELET RICH PLASMA ON MESENCHYMAL STEM CELLS (MSCs) DIFFERENTIATION INTO CHONDROBLAST
}

\author{
Dwikora Novembri Utomo ${ }^{1 *}$, I Gde Adi Widiastana ${ }^{2}$ \\ ${ }^{1}$ Senior Consultant of Orthopaedic and Traumatology Department, Faculty of Medicine, \\ Universitas Airlangga, Dr Soetomo General Hospital, Surabaya \\ ${ }^{2}$ Resident of Orthopaedic and Traumatology Department, Faculty of Medicine, Universitas \\ Airlangga, Dr Soetomo General Hospital, Surabaya \\ *Correspondence: Dwikora Novembri Utomo, Senior Consultant of Orthopaedic and \\ Traumatology Department, Faculty of Medicine, Universitas Airlangga, Jl. Mayjen Prof. Dr. \\ Moestopo 6-8, Surabaya \\ E-mail :dwikora_utomo@yahoo.com
}

\begin{abstract}
ABSTRAK
Penambahan platelet rich plasma ke kultur mesenchymal stem cell pada media pertumbuhan dan media kondrogenik berpengaruh pada proliferasi dan diferensiasi stem cell menjadi kondroblas belum diketahui efeknya. Penelitian ini bertujuan untuk mengetahui efek platelet rich plasma pada diferensiasi mesenchymal stem cell dan proliferasi menjadi kondroblas pada media invitro. Desain rancangan kelompok kontrol acak post test. Darah diambil dari vena kelinci untuk diproses menjadi platelet rich plasma (PRP). Mesenchymal stem cell (MSC) dipanen dari sumsum tulang kelinci untuk dibudidayakan. Kultur MSC dibagi menjadi tiga kelompok modifikasi. Kelompok pertama adalah kombinasi MSC yang ditambahkan dengan Complete Control Medium (CCM) dan Chondrogenic Differentation Medium (CDM) tanpa PRP sebagai kelompok kontrol. Kelompok kedua memiliki kombinasi yang sama dengan kelompok pertama dengan penambahan PRP 5\%. Kelompok ketiga memiliki kombinasi yang sama dengan kelompok pertama dengan penambahan PRP $10 \%$. Hasilnya dievaluasi dalam 21 hari sebagai berikut. Kelompok yang menerima penambahan PRP 5\% memiliki peningkatan kondroblas yang signifikan dibandingkan kelompok tanpa penambahan PRP $(\mathrm{p}=0,033)$. Hasil yang sama juga terjadi pada kelompok yang menerima penambahan PRP $10 \%$ dibandingkan kelompok tanpa penambahan PRP $(\mathrm{p}=0,028)$. Tidak ada perbedaan yang signifikan antara hitung kedua dan kelompok ketiga $(\mathrm{p}=0,203)$. Ada efek signifikan platelet rich plasma pada diferensiasi mesenchymal stem cell dan proliferasi menjadi kondroblas pada media in vitro.
\end{abstract}

Kata kunci : kondroblas, medium kultur lengkap, mesenchymal stem cell, platelet rich plasma

\section{ABSTRACT}

The addition of platelet rich plasma to mesenchymal stem cell culture on growth media and chondrogenic media had any effect on stem cell's proliferation and differentiation into chondroblast has not been determined. This research is to find out the effect of platelet rich plasma on mesenchymal stem cell's differentiation and proliferation into chondroblast on in vitro media. Randomized control group posttest only design. Blood was taken from the rabbit's vein to be processed into platelet rich plasma (PRP). Mesenchymal Stem Cell (MSC) was harvested from the bone marrow of the rabbit to be cultured. The MSC's culture were divided into three groups of modification. The first group was combination of MSC added with Complete Culture Medium (CCM) and Chondrogenic Diferentation Medium (CDM) without PRP as control group. The second group had the same combination as the first group with extra 5\% PRP. The third group had the same combination as the first group with extra 10\% PRP. The results were evaluated in the following 21 days. The group that received extra 5\% PRP had significant increase of 
chondroblast count compared to the group without PRP addition ( $\mathrm{p}=0,033)$. The same result also occured on the groups that received extra 10\% PRP compared to the group without PRP addition $(\mathrm{p}=0,028)$. There were no significant diferences between both the second and the third groupchondroblast count $(\mathrm{p}=0,203)$. There was a significant effect of platelet rich plasma on mesenchymal stem cell's diferentiation and proliferation into chondroblast on invitro media.

Keywords : chondroblast, complete culture medium, mesenchymal stem cell, platelet rich plasma

\section{PENDAHULUAN}

Kartilago atau tulang rawan adalah sutau jaringan yang kuat, bersifat semi transparan, elastik dan fleksibel, yang terdiri dari kondrosit dan kondroblas yang tersebar di antara material lipoprotein, dan diperkuat oleh serat-serat kolagen. Bagian luar dari kartilago dilapisi oleh serabut membran yang tebal dan kuat yang disebut sebagai perikondrium. Pada kartilago tidak ditemukan pembuluh darah dan saraf, sehingga jika terjadi kerusakan maka akan sulit terjadi penyembuhan. Kartilago sendi mempunyai beberapa fungsi, antara lain: sebagai penutup permukaan sendi, mengurangi gesekan antar tulang di sendi sehingga mencegah kerusakan, dan juga berperan sebagai penahan goncangan. ${ }^{1}$

Degenerasi dan cedera pada tulang rawan sendi cenderung meningkat disebabkan oleh meningkatnya angka harapan hidup dan meningkatnya angka kejadian trauma. Secara alami tulang rawan sendi akan mengalami degenerasi dan regenerasi. Proses penyembuhan kartilago diatur oleh kondrosit yang memproduksi matriks ekstraseluler proteoglikan dan kolagen. Beberapa respon terhadap penyembuhan luka pada kartilago tidak akan diganti dengan tipe kolagen dan preoteoglikan yang sesuai dan akan menyebabkan fungsi yang abnormal. Terutama pada kartilago artikular, jika terjadi cedera maka akan sulit untuk regenerasi karena lambatnya aktivitas mitotik dari kondrosit dan jaringan yang avaskular. Meskipun dalam kondisi yang ideal, proses perbaikan kerusakan tulang rawan sendi masih sulit karena lambatnya proliferasi kondrosit jika dibandingkan dengan jaringan parut. $^{2}$

Beberapa cara untuk melakukan penanganan terhadap kerusakan tulang rawan sendi antara lain: Traditional Palliative (lavage, chondroplasty), bone marrow stimulation techniques (microfractures), osteochondral autologous transplantation, osteochondral allograft transplantation, cell-based therapy (Autologous Chondrocytes Implantation (ACI), Matrix Induced Chondrocytes Implantation (MACI), 


\section{Mesenchymal stem cells (MSCs) implantation). ${ }^{3-4}$}

Kemajuan di bidang kedokteran meliputi kedokteran molekuler, biologi molekuler, rekayasa jaringan dan genetik telah membuka cakrawala baru dalam penanganan berbagai macam kondisi kelainan sistem muskuloskeletal. Sebagai contoh kemampuan untuk mengisolasi dan kultur mesenchymal stem cells (MSCs) telah membuka wacana baru dalam pengobatan defek tulang rawan sendi. Mesenchymal stem cells (MSCs) adalah sel multipoten yang dapat berdeferensiasi ke dalam beberapa sel selama proses penyembuhan cedera jaringan. MSCs dapat berdiferensiasi menjadi collagen, osteoblast pembentuk tulang, kondrosit pembentuk tulang rawan sendi dan lainnya. Sel itu secara bersama-sama mempunyai kemampuan untuk meregenerasi kerusakan jaringan yang disebabkan oleh cedera, perubahan degenerasi, dan osteoartritis. ${ }^{1}$

Diferensiasi MSC menjadi berbagai jaringan seperti tulang, kartilago dan lemak telah dipelajari oleh banyak laboratorium. Seperti telah dijelaskan sebelumnya, stimulus dan lingkungan yang tepat akan menentukan diferensiasi MSC menjadi sel yang spesifik. $^{5}$ Diferensiasi MSC menjadi kondroblas atau disebut diferensiasi kondroblastik terjadi bila MSC ditumbuhkan pada media dengan kondisi yang memenuhi syarat tertentu yaitu dalam medium nutrisi yang bebas serum dan mengandung komponen TGF- $\beta$. Bila kondisi ini terpenuhi, MSC akan kehilangan morfologi fibroblastiknya dan mulai mengrekspresikan berbagai macam komponen matriks ekstraseluler. Proses ini melibatkan biosintesis glikosaminoglikan dan diikuti dengan perubahan morfologi sel. Pada proses awal kondrogenesis terdapat perubahan progresif dari struktur kondrotinsulfat yang dipengaruhi oleh TGF- $\beta 1,2$, dan 3 . Selama proses diferensiasi, dengan pengaruh TGF- $\beta$, MSC akan mensitesis aggrecan, link protein, fibromodulin, decorin dan chondroadherin, komponen normal dari matriks kartilago. ${ }^{6}$

Pada perkembangan terbaru diketahui bahwa growth factor ternyata memegang peranan penting dalam melakukan regenerasi jaringan termasuk tulang rawan sendi. Tetapi, penjelasan tentang bekerjanya senyawa ini pada kondrosit belum dipaparkan secara utuh, namun nampaknya hal ini berhubungan dengan tempat reseptor sel permukaan pada sel yang bertanggung jawab. Beberapa growth factor yang sangat berpengaruh dalam tulang rawan sendi adalah transforming growth factor-beta $(T G F-\beta)$, platelet derived growth factor 
$(P D G F)$ dan insulin growth factor (IGF) dan lain-lain. ${ }^{7}$

Platelet rich plasma selama ini banyak digunakan pada injeksi intraartikular. Diduga bahan ini dapat memperbaiki kerusakan tulang rawan karena PRP mengandung berbagai macam growth factor (platelet derived growth factor (PDGF), transforming growth factor $(T G F)$, platelet factor interleukin (IL), platelet derived angiogenesis factor (PDAF), vascular endhotelial growth factor (VEGF), epidermal growth factor $(E G F)$, insulin-like growth factor $(I G F)$, dan fibronektin) yang sama seperti yang diperlukan oleh MSCs untuk berdiferensiasi menjadi kondroblas. Salah satu growth factor penting yang diperlukan adalah TGF- $\beta .^{5}$

Tujuan penelitian ini adalah untuk mengetahui pengaruh platelet rich plasma terhadap mesenchymal stem cells yang dikultur dengan media pertumbuhan. Dianalisis apakah platelet rich plasma dapat berfungsi seperti media kondrogenik yang menyebabkan diferensiasi dan proliferasi dari MSCs menjadi kondroblas.

\section{METODOLOGI PENELITIAN}

Penelitian ini adalah eksperimental murni dengan rancangan penelitian Rancangan Acak Kelompok (RAK). Dilakukan pengukuran variabel pada hewan coba hanya setelah diberikan perlakuan. $^{8}$

Sampel penelitian ini hewan kelinci putih New Zealand jantan. Diambil darah vena dari kelinci tersebut untuk dibuat platelet rich plasma (PRP), kemudian diukur konsentrasi plateletnya. Kemudian dilakukan kultur Mesenchymal Stem Cell (MSCs) yang diambil dari Bone Marrow kelinci, ditumbuhkan pada media Complete Culture Medium (CCM) ditambah dengan Chondrosite Differentiation Medium (CDM), medium selanjutnya diganti setiap 3 hari dilakukan inkubasi selama 21 hari dalam suatu inkubator dengan suhu $37^{\circ} \mathrm{C}$ dengan $\mathrm{CO}_{2} 5 \%$.

Pada kultur MSCs diberikan tiga perlakuan yaitu perlakuan pertama, Mesenchymal Stem Cell (MSCs) ditambahkan Complete Culture Medium (CCM) ditambah dengan Condrosit Differentiation Medium (CDM) tanpa PRP sebagai kontrol. Perlakuan kedua, Mesenchymal Stem Cell (MSCs) ditambahkan Complete Culture Medium (CCM) ditambah dengan Condrosit Differentiation Medium (CDM) ditambahkan 5\% PRP dan pada medium ketiga Mesenchymal Stem Cell (MSCs) ditambahkan Complete Culture Medium (CCM) ditambah dengan Condrosit Differentiation Medium (CDM) ditambahkan 10\% PRP. Setelah dilakukan 
kultur dan penggantian media secara berkala, maka dilakukan harvesting pada hari ke-21. Kemudian di lakukan pencucian pada masing-masing media kultur dan diferensiasi kondroblas diketahui dengan melakukan pemeriksaan Histopatologis, yaitu menghitung jumlah kondroblas yang terbentuk per-lapang pandang mikroskop.

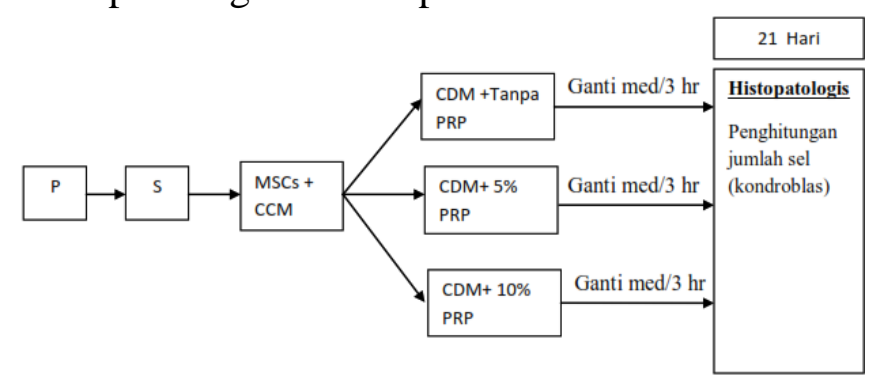

Gambar 1. Alur Penelitian

\section{HASIL DAN PEMBAHASAN}

Dari hasil pembuatan PRP dengan 5 metode yang berbeda didapatkan peningkatan konsentrasi platelet dalam persen dalam tabel sebagai berikut:

Tabel 1. Hasil Konsentrasi PRP menggunakan 5 metode

\begin{tabular}{|c|c|c|c|c|c|}
\hline PRP & $\begin{array}{c}\text { Metode } \\
1(\%)\end{array}$ & $\begin{array}{c}\text { Metode } \\
2(\%)\end{array}$ & $\begin{array}{c}\text { Metode } \\
3(\%)\end{array}$ & $\begin{array}{c}\text { Metode } \\
4(\%)\end{array}$ & $\begin{array}{c}\text { Metode } \\
5(\%)\end{array}$ \\
\hline Sampel 1 & 600 & 517 & 306 & 434 & 153 \\
\hline Sampel 2 & 617 & 524 & 285 & 417 & 166 \\
\hline Sampel 3 & 620 & 520 & 320 & 440 & 175 \\
\hline Sampel 4 & 616 & 533 & 309 & 416 & 163 \\
\hline Sampel 5 & 606 & 513 & 310 & 416 & 172 \\
\hline Sampel 6 & 614 & 517 & 307 & 435 & 171 \\
\hline Sampel 7 & 610 & 500 & 306 & 434 & 174 \\
\hline Sampel 8 & 600 & 463 & 303 & 373 & 163 \\
\hline Sampel 9 & 600 & 477 & 309 & 406 & 153 \\
\hline Mean & $\mathbf{6 0 9 \%}$ & $\mathbf{5 0 7 \%}$ & $\mathbf{3 0 6 \%}$ & $\mathbf{4 1 9 \%}$ & $\mathbf{1 6 5 \%}$ \\
\hline
\end{tabular}

Keterangan : metode 1 memiliki prosentase terbesar $(609 \%)$
Dari hasil analisa Growth Factor PDGF-BB dan TGF- $\beta 1$ pada PRP, PPP, plasma, dan serum sebagai kontrol didapatkan peningkatan kadar growth factor sebagai berikut:

Tabel 2. Hasil analisa kadar Growth Factor (Platelet, PDGF-BB dan TGF- $\beta 1$ )

\begin{tabular}{|c|c|c|c|}
\hline Sampel & $\begin{array}{c}\text { Mean } \\
\text { (platelet } / \mu \mathrm{l})\end{array}$ & $\begin{array}{c}\text { Mean } \\
\text { PDGF-BB } \\
(\mathrm{pg} / \mathrm{ml})\end{array}$ & $\begin{array}{c}\text { Mean TGF- } \beta 1 \\
(\mathrm{pg} / \mathrm{ml})\end{array}$ \\
\hline $\begin{array}{c}\text { PRP } \\
\text { metode 1 }\end{array}$ & 1.769 .200 & 56.778 & 96.278 \\
\hline $\begin{array}{c}\text { PRP } \\
\text { metode } 4\end{array}$ & 1.215 .200 & 37.889 & 89.000 \\
\hline $\begin{array}{c}\text { PPP } \\
\text { metode } 1\end{array}$ & 32.800 & 2.180 & 6.047 \\
\hline $\begin{array}{c}\text { PPP } \\
\text { metode } 4\end{array}$ & 36.350 & 5.541 & 13.000 \\
\hline Plasma & 178.400 & 4.209 & 7.111 \\
\hline Serum & 289.200 & 13.222 & 21.850 \\
\hline
\end{tabular}

Keterangan : metode 1 memiliki kadar tertinggi pada kadar $P D G F-B B$ dan $T G F-\beta 1$

Dari berbagai macam metode pembuatan PRP didapatkan peningkatan konsentrasi platelet paling tinggi pada metode 1, yaitu rata-rata meningkat 6,09 kali (609\%). Pada penilaian konsentrasi Growth Factor PDGF-BB didapatkan hasil tertinggi PRP dengan metode 1, yaitu $56.778 \mathrm{pg} / \mathrm{ml}(4,36 \mathrm{kali}$ atau $436 \%)$ dari kontrol yaitu $13.222 \mathrm{pg} / \mathrm{ml}$. Pada penilaian konsentrasi growth factor TGF- $\beta 1$ didapatkan hasil tertinggi PRP dengan metode 1, yaitu $96.278 \mathrm{pg} / \mathrm{ml}$ (4,4 kali atau $440 \%$ ) dari kontrol yaitu $21.850 \mathrm{pg} / \mathrm{ml}$. 


\section{KESIMPULAN DAN SARAN}

Diantara lima metode pembuatan Platelet Rich Plasma, metode paling optimal untuk mendapatkan konsentrasi tertinggi platelet adalah menggunakan dua tahap sentrifugasi, pertama dengan kecepatan 3000 rpm selama 3 menit dan 45 detik, kedua dengan kecepatan 3000 rpm selama 10 menit. Konsentrasi platelet 6,09 kali (609\%). Konsentrasi growth factor tertinggi didapatkan pada metode kedua dengan peningkatan konsentrasi TGF- $\beta 1$ sebesar 4,36 kali $(436 \%)$ dan peningkatan konsentrasi PDGF-BB sebesar 4,40 kali (440\%) dari kontrol.

\section{REFERENSI}

1. Ulrich-Vinther M, Maloney MD, Schwarz EM, Rosier R, O'Keefe RJ. Articular cartilage biology. The Journal of the American Academy of Orthopaedic Surgeons. 2003; 11(6): 421-30.

2. Buckwalter JA, Mankin HJ. 1997. An International Course Lecture. J. Bone Joint Surgery. 79-A; 600-11.

3. Gobbi A. and Bathan L. 2009. Biological Approach for Cartilage Repair. Journal Knee Surgery, 22:3644.

4. Getgood et al. 2009. Articular Cartilage Tissue Engineering: Today's research, tomorrow practice? $J$ Bone and Joint Surgery, 91(5) p: 565-576.

5. Gimble JM, Guilak F, Nuttall ME, Sathishkumar S, Vidal M, Bunnell BA. In vitro Differentiation Potential of Mesenchymal Stem Cells. Transfusion Medicine and Hemotherapy. 2008;35(3):228-38.
6. Russell KC, Phinney DG, Lacey MR, Barrilleaux BL, Meyertholen KE, O'Connor KC. In vitro high-capacity assay to quantify the clonal heterogeneity in trilineage potential of mesenchymal stem cells reveals a complex hierarchy of lineage commitment. Stem cells (Dayton, Ohio). 2010;28(4):788-98.

7. Mankin, A. S. 1995. Selection for spontaneous and engineered mutations in the rRNA genes in halophilic archaea. In Archaea, A Laboratory Manual (Robb, F. T., Place, A. R., Sowers, K. R., Schreier, H. J., DasDarma, S. \& Fleischmann, E. M., eds), pp. 209-216, Cold Spring Harbor Laboratory Press, Cold Spring Harbor, NY.

8. A. Watik Pratiknya, 2008. Dasardasar Metodologi Penelitian Kedokteran dan Kesehatan. Rajawali Pers.

9. Breinan HA, Minas T, Hsu H-P, Nehrer S, Sledge CB, Spector $M$. 1997. Effect of cultured autologous chondrocytes on repair of chondral defects in a canine model. J. Bone Joint Surg. 1997; 79-A: 1439-1451.

10. Barry F, Boynton RE, Liu B, Murphy JM. 2001. Chondrogenic differentiation of mesenchymal stem cells from bone marrow: differentiation-dependent gene expression of matrix component. Experimental Cell Research, 268:189-200. 